\title{
Do landfills affect the environmental quality of nearby streams?
}

\author{
Leandro Schlemmer Brasil ${ }^{1 *}$ \\ Karina Dias-Silva ${ }^{2}$ \\ ${ }^{1}$ Programa de Pós Graduação em Zoologia \\ Universidade Federal do Pará e Museu Paraense Emílio Goeldi \\ Avenida Perimetral, 1901/1907, Terra Firme, CEP 66017-970, Belém - PA, Brasil \\ ${ }^{2}$ Programa de Pós Graduação em Biodiversidade e Conservação, Universidade Federal do Pará \\ Altamira - PA, Brasil \\ * Autor para correspondência \\ brasil_biologia@hotmail.com
}

Submetido em 06/05/2017

Aceito para publicação em 04/09/2017

\section{Resumo}

A implementação de aterros sanitários mantém a qualidade ambiental de riachos adjacentes? Quando mal depositados, os resíduos sólidos contaminam o solo, a água e o ar, causando sérios problemas para a conservação da biodiversidade. A Política Nacional de Resíduos Sólidos (PNRS) prevê que os municípios garantam a qualidade ambiental nas regiões dos aterros sanitários. Neste contexto, nosso objetivo foi avaliar comunidades de insetos aquáticos de um riacho com trechos a jusante e montante de um aterro sanitário. Nossa hipótese é que não haverá diferenças na comunidade entre os trechos (jusante e montante) partindo da premissa que aterros que seguem a PNRS não causam danos ambientais nas áreas adjacentes. Não houve alteração em qualquer aspecto da comunidade relacionada ao aterro sanitário. A única mudança observada na comunidade ocorreu entre as estações seca e chuvosa, que se relacionam com a sazonalidade e suas mudanças nas condições ambientais da água ao longo do ano. Nosso estudo, embora breve, mostra evidências primárias e pioneiras de que o PNRS pode contribuir positivamente para a conservação da qualidade biótica dos ambientes aquáticos, reforçando ainda mais a necessidade de sua implementação imediata em todo o país.

Palavras-chave: Bioindicadores; Política Nacional de Resíduos Sólidos; Poluição; Qualidade da água

\section{Abstract}

When inappropriately disposed, solid waste may contaminate the soil, water and air, leading to severe negative impacts on biodiversity. The Brazilian National Policy for Solid Waste (PNRS) requires municipalities to ensure the environmental quality of landfills. Accordingly, our objective was to evaluate the community of aquatic insects in a stream with stretches downstream and upstream of a sanitary landfill. Our hypothesis was that there will be no differences in insect community between the stretches (downstream and upstream) on the basis of the premise that landfills abiding by the PNRS do not cause environmental damage to nearby areas. There was no change in any aspect of the composition of the macroinvertebrate community as a result of the landfill. The only changes observed in the macroinvertebrate communities occurred between the dry and rainy seasons, which were related to the seasonality and consequent changes in the environmental conditions of the water over the year. Our study, although limited, showed primary and pioneering evidence that the PNRS can contribute positively to the conservation of the biotic quality of aquatic environments, further reinforcing the need for immediate implementation of the PNRS throughout the country.

Key words: Bioindicators; Brazilian National Policy for Solid Waste; Pollution; Water quality 


\section{Introduction}

Historically, Brazil has neglected problems associated with the accumulation and inappropriate disposal of waste in open areas (DE FRANCESCHI et al., 2017). Inadequate disposal of solid waste releases gases that are both harmful to human health and contribute to global warming (GOMES et al., 2012), and produces slurry, which is highly damaging to organisms and the environment (CELERE et al., 2007). Furthermore, landfills are favorable habitats for disease vectors, such as mice, cockroaches and flies (POSSAMAI et al., 2006).

In 2010, Brazilian Law No. 12.305/10 established a National Policy for Solid Waste (Política Nacional de Resíduos Sólidos - PNRS), an important benchmark in the country's fight to address the environmental, social and economic impacts of unsuitable disposal of solid waste, and safeguarding of environmental quality, species conservation and public health in areas surrounding landfills (MMA, 2014).

Among the many problems caused by inappropriate disposal of waste, the contamination of aquatic environments may be one of the most serious, due to paradoxical increases in waste production (OLIVEIRA; PASQUAL, 2004; SAMUEL-ROSA et al., 2012). This has been even more serious in a period of severe water scarcity in many regions of Brazil since 2015 (FREITAS; DEL GAUDIO, 2015). Aquatic environments, such as streams, rivers and lakes, are considered vulnerable to environmental changes (PRIMACK; RODRIGUES, 2001), because they reflect changes in the landscape across entire drainage basins (ALLAN; CASTILLO, 2007). Fish and invertebrate assemblages are subject to changes in species richness, abundance of individuals and community composition as a result of human activities (ALLAN, 2004).

Among the groups most vulnerable to these changes are aquatic insects (SIEGLOCH et al., 2017). Considering that other anthropogenic activities that impact the environment less than do dumps, such as agriculture and livestock (DIAS-SILVA et al., 2010; BRASIL et al., 2014a; 2014b; OLIVEIRA-JUNIOR et al., 2015), activities of traditional populations (FARIA et al., 2017) and urbanization (MONTEIRO JÚNIOR et al., 2014), already cause considerable changes in aquatic insect communities, slurry pollution is then expected to be even more serious. These changes in biota due to anthropic alterations can occur on a taxonomic scale, affecting richness (number of species), abundance (number of individuals) or composition of communities (DIAS-SILVA et al., 2010; BRASIL et al., 2014a; 2014b; OLIVEIRA-JUNIOR et al., 2015; FARIA et al., 2017), or they can impact functional (LUIZA-ANDRADE et al., 2017) and/or morphological (PINTO et al., 2012) diversity. These characteristics make aquatic insects an excellent bioindicator of environmental quality (ROSENBERG; RESH, 1993), allowing the monitoring of anthropogenic impacts over time and/or space (RUARO et al., 2016).

Our objective was to determine the influence of a landfill on a community of aquatic insects. Our hypothesis was that there will be no differences in the community between the stretches with and without influence of the landfill. This was based on the premise that landfills abiding by the PNRS do not cause environmental damage to nearby areas. If there is a significant effect of the landfill on aquatic insect communities, it is expected that the site with direct influence will differ in community composition compared to others, especially relative to the upstream site. The null hypothesis, that there is no effect of the landfill on aquatic invertebrate communities, would be accepted if there were no difference between the communities of the three sites examined.

\section{Material and Methods}

\section{Study area}

We monitored the environmental impact on streams under the influence of a landfill in northern Mato Grosso State, Brazil (lat. $-12.894^{\circ}$, long. $-55.714^{\circ}$ ) using aquatic insect communities sampled in three streams. Sites were located downstream of (direct effect, lat. $-12.907^{\circ}$, long. $-55.704^{\circ}$ ), next to (indirect effect, lat. $-12.903^{\circ}$, long. 
$-55.713^{\circ}$ ) and upstream of (without effect, lat. $-12.892^{\circ}$, long. $-55.733^{\circ}$ ) a sanitary landfill. The landfill selected for study stores the solid waste of eight nearby cities: Sorriso, Lucas do Rio Verde, Nova Mutum, Cláudia, Vera, Tapurah, Nova Ubiratam and Ipiranga do Norte, all located in Mato Grosso, which together total an estimated 221,947 inhabitants (IBGE, 2015). Measures for mitigating impacts caused by waste include a triple sealed $1.5 \mathrm{~mm}$ high-density polyethylene layer, enveloped in two layers of $0.50 \mathrm{~m}$ of compacted clay. In addition, monitoring wells and an effluent treatment system (slurry) have been installed to monitor surface water and groundwater quality (SANORTE, 2014).

\section{Data sampling}

For the aquatic insect monitoring, three sampling sites differing in their proximity to the landfill and contamination potential were established: site 3 was located downstream of the landfill and under its direct influence; site 2, the indirect influence site, was located in an area close to the landfill and with risk of contamination by rainwater; and site 1 was located upstream of the landfill and therefore considered free of influence from the landfill (Figure 1).

At each site, three plots were established $200 \mathrm{~m}$ from one another, and in each plot, three portions of substrate from the benthic zone were collected using the edge of a strainer ( $20 \mathrm{~cm}$ in diameter and 2-mm mesh), following methods described by Cabette et al. (2010). Sampling was conducted in both the dry season in July 2014, and rainy season in January 2015.

FIGURE 1: Spatial distribution of the sampling sites located in a Cerrado stream in Central-West Brazil: without influence of landfill (site 1), indirect influence of landfill (site 2) and direct influence of the landfill (site 3). The letters (A, B and C) represent repeat sampling points within sites.

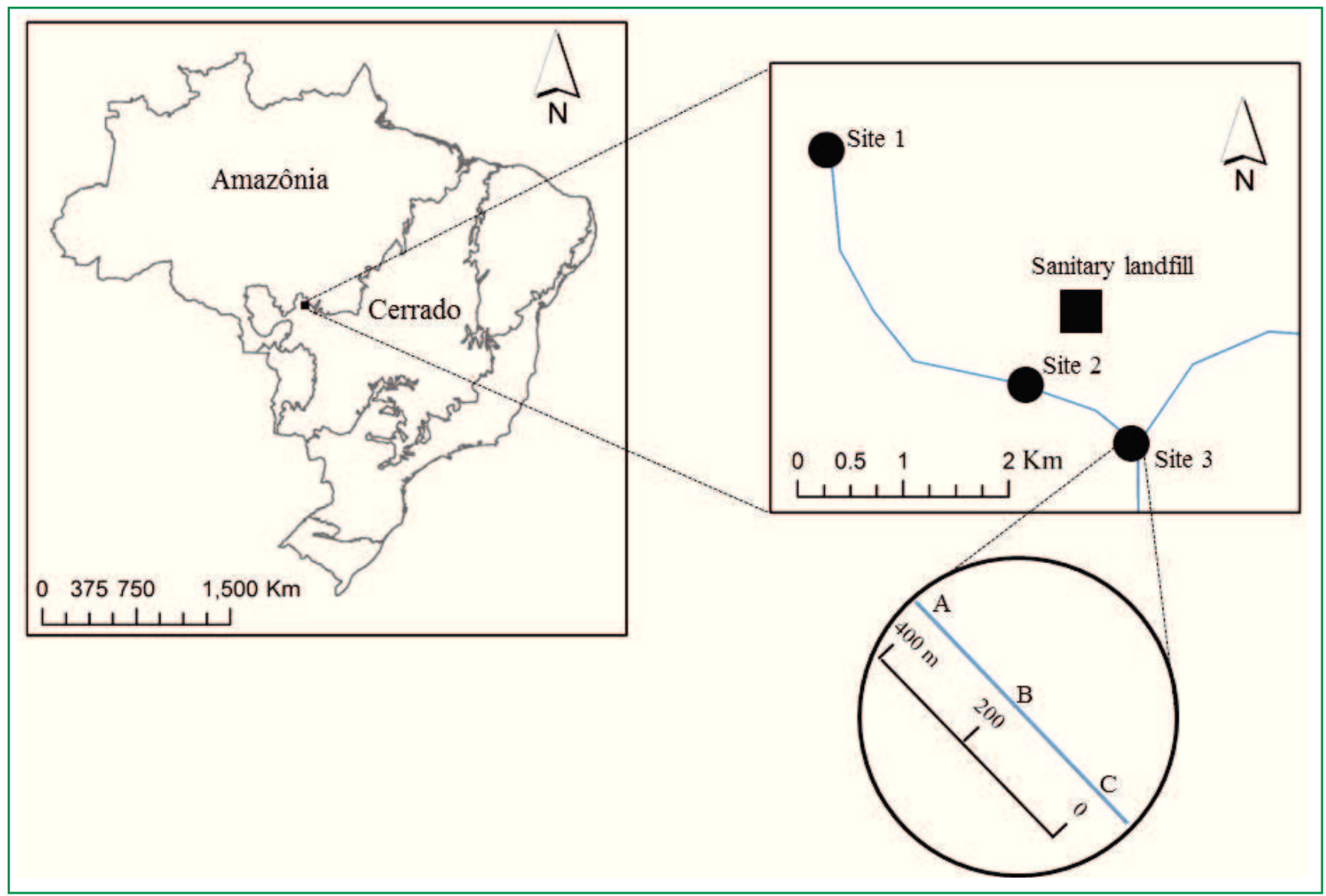




\section{Data analysis}

To determine possible changes in the structure of communities due to the level of influence of the landfill and between dry and rainy season, we compared the parameters abundance (number of specimens collected at each sampling point) and richness of genera (number of genera found at each sampling point) and the composition matrix of genera. To compare abundance of specimens between the sample points, we considered two factors, the influence of the landfill (factor 1) and period of the year (factor 2), where we did an analysis of variance with two factors (two-way ANOVA). Likewise, we compared richness of genera using twoway ANOVA. For the two ANOVAs, the levels of the factors influence of the landfill and period of the year were: direct influence (DI), indirect influence (II) and without influence (WI) of the landfill, and dry and rainy, respectively. For the two ANOVAs, we performed prior logarithmic transformation $(\log +1)$ for abundance of individuals and richness of genera. This avoided excessive dominance of the most common taxa in the results (ZAR, 2010).

To investigate differences in composition between sites with different influences of the landfill, and between seasons (dry and wet), we used PERMANOVAs with taxon abundance matrix using 999 randomizations (ANDERSON; WALSH, 2013), For this test, we use the between the treatments using the composition matrix with pairwaise test. To visualize the differences in the composition tested in PERMANOVA, we made an ordination - principal coordinates analysis (PCoA). We did a transformation $(\log +1)$ and created a similarity matrix of Bray-Curtis distance for PCoA of the composition matrix with abundance data (LEGENDRE; LEGENDRE, 2012). For every test, $\alpha=5 \%(p<0.05)$ indicated different from a random effect. All statistical analyses were done in software R (R Core Development Team 2017). For ANOVAs, we used the function aov \{stats\}, for PERMANOVAs the function adonis \{vegan\} (OKSANEN et al., 2007) and for PCoA the function cmdscale $\{$ stats .

\section{Results}

A total of 174 specimens were collected during sampling (Table 1). Richness of genera and abundance of individuals of aquatic insects did not differ between sites with different levels of influence of the landfill (richness of genera: $F_{(2,12)}=0.66 ; p=0.535$, and abundance of individuals: $\left.\mathrm{F}_{(2,12)}=0.18 ; \mathrm{p}=0.836\right)$, but both richness of genera and abundance of individuals were markedly higher in the dry season compared to the rainy season (Figure 2A,B). Furthermore, no significant effect of the interaction between study site and season was found for either richness of genera $\left(F_{(2,12)}=3.61 ; p=0.059\right)$ or abundance of individuals $\left(\mathrm{F}_{(2,12)}=1.58 ; \mathrm{p}=0.246\right)$ of aquatic insects. The taxon composition did not differ between sites with different influence of the landfill (PERMANOVA, $p s e u d o F=2.541, p=0.019)$ (Figure 3), but did differ between dry and rainy seasons in post-hoc (pairwise test) (Table 2). 
TABLE 1: Checklist of taxa and abundance of individuals collected at sites of a Cerrado stream with direct (Site 3) and indirect (Site 2) influence and without influence (Site 1) of a landfill. The letters (A, B and C) represent the three replicate samples taken at each site.

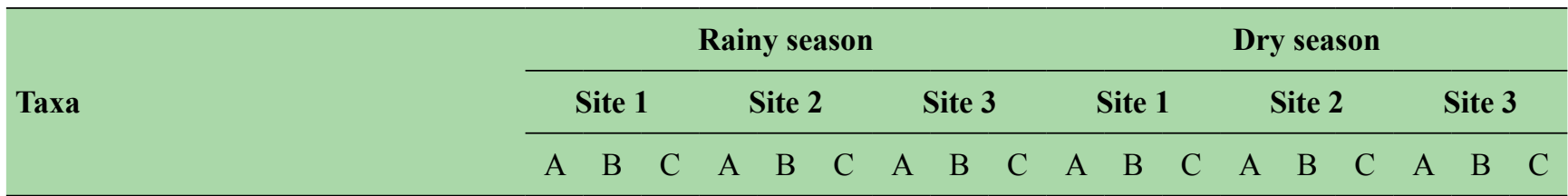

Ephemeroptera

Americabaetis Kluge, 1992

$$
\begin{array}{llllllllllllllllll}
0 & 0 & 0 & 0 & 0 & 0 & 0 & 0 & 0 & 2 & 0 & 0 & 0 & 0 & 0 & 0 & 0 & 0
\end{array}
$$

\section{Heteroptera}

Curicta Stal, 1861

Limnocoris Stal, 1860

Progomphus Selys, 1854

Ranatra Fabricius, 1790

Rhagovelia Mayr, 1865

$$
\begin{array}{llllllllllllllllll}
0 & 0 & 0 & 0 & 0 & 0 & 0 & 0 & 0 & 0 & 0 & 0 & 0 & 0 & 2 & 0 & 0 & 0 \\
0 & 0 & 0 & 0 & 0 & 0 & 0 & 0 & 0 & 0 & 0 & 0 & 0 & 0 & 0 & 0 & 2 & 0 \\
0 & 0 & 0 & 0 & 0 & 0 & 0 & 0 & 0 & 0 & 2 & 2 & 0 & 0 & 2 & 0 & 0 & 4 \\
0 & 0 & 0 & 0 & 0 & 0 & 0 & 0 & 0 & 0 & 0 & 0 & 0 & 0 & 0 & 2 & 0 & 0 \\
0 & 0 & 0 & 0 & 0 & 0 & 0 & 0 & 0 & 0 & 2 & 0 & 0 & 0 & 0 & 0 & 0 & 0
\end{array}
$$

\section{Odonata}

Argia Rambur, 1842

Elasmothemis Westfall, 1988

Epigomphus Hagen in Selys, 1854

Hetaerina Hagen in Selys, 1853

Perithemis Hagen, 1861

\section{Plecoptera}

Anacroneuria Klapále, 1909

Macrogynoplax Enderlein, 1909

\section{Trichoptera}

Leptonema Guérin-Meneville, 1843

Marilia Müller, 1878

Nectopsche Müller, 1878

Oecetis McLachlan, 1877

Smicridae McLachlan, 1871

$$
\begin{array}{llllllllllllllllll}
0 & 0 & 0 & 0 & 0 & 0 & 1 & 0 & 0 & 0 & 0 & 0 & 2 & 0 & 0 & 0 & 0 & 0 \\
0 & 0 & 0 & 0 & 0 & 0 & 0 & 1 & 0 & 0 & 0 & 0 & 0 & 0 & 0 & 0 & 0 & 0 \\
0 & 0 & 0 & 0 & 0 & 0 & 0 & 1 & 0 & 0 & 0 & 0 & 0 & 0 & 0 & 0 & 0 & 0 \\
0 & 0 & 0 & 0 & 0 & 0 & 0 & 1 & 0 & 0 & 0 & 0 & 0 & 0 & 0 & 0 & 0 & 0 \\
0 & 0 & 0 & 0 & 0 & 0 & 0 & 0 & 0 & 0 & 0 & 2 & 2 & 0 & 4 & 0 & 0 & 4
\end{array}
$$

$$
\begin{array}{llllllllllllllllll}
0 & 0 & 2 & 1 & 0 & 0 & 4 & 0 & 1 & 10 & 36 & 0 & 0 & 14 & 2 & 6 & 4 & 0 \\
0 & 0 & 0 & 0 & 0 & 0 & 0 & 0 & 0 & 0 & 0 & 2 & 0 & 0 & 0 & 0 & 0 & 0
\end{array}
$$


FIGURE 2: Analysis of variance of the richness of genera (A) and abundance of individuals (B), considering the seasons sampled in 2015.

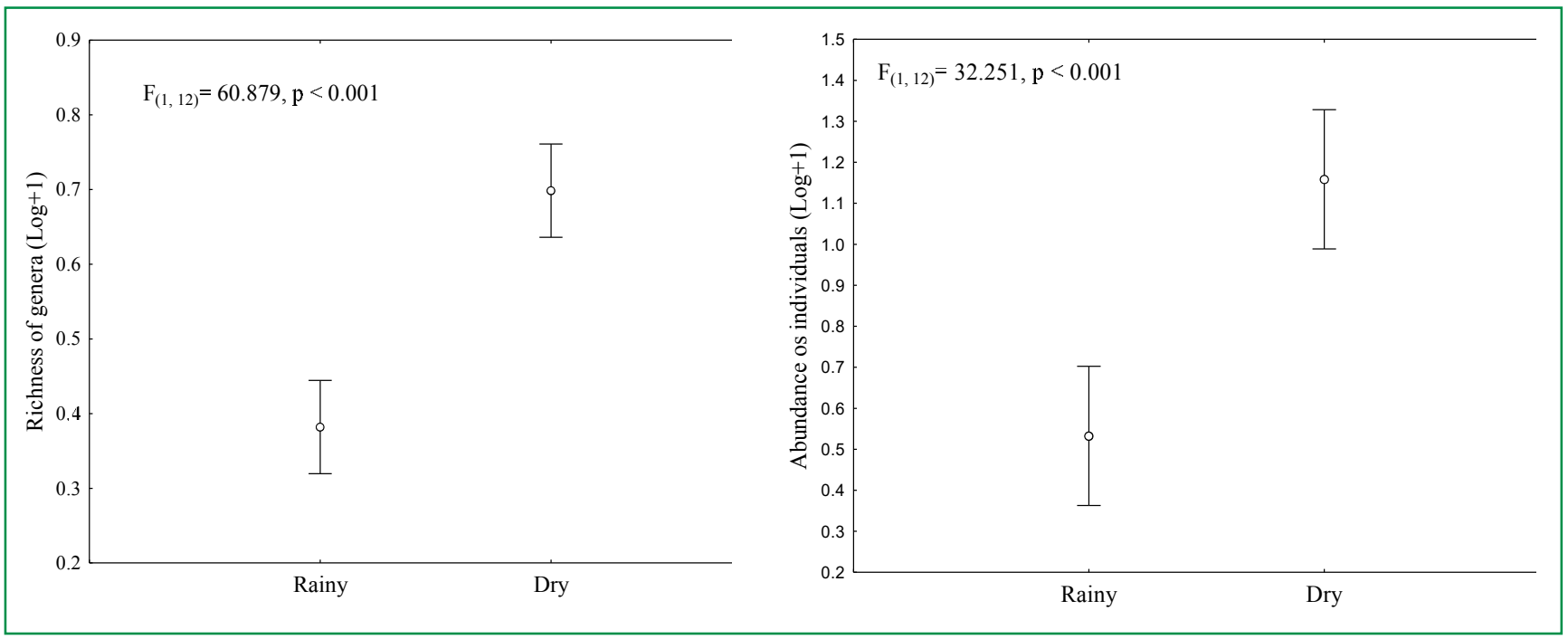

TABLE 2: Comparison of taxon composition between sites of a Cerrado stream with direct influence (DI), indirect influence (II) and without influence (WI) of a landfill.

\begin{tabular}{ccc}
\hline Comparison & pseudoF & p \\
\hline DI x II x WI & 1.289 & 0.159 \\
DI x II & 2.969 & 0.097 \\
DI x WI & 1.048 & 0.493 \\
II x WI & 2.961 & 0.104 \\
\hline
\end{tabular}

FIGURE 3: Principal coordinates analysis (PCoA) of benthic communities of streams with direct influence (1), indirect influence (2) and without influence (3) of a landfill in the dry and rainy seasons, at the sampled sites in 2015.

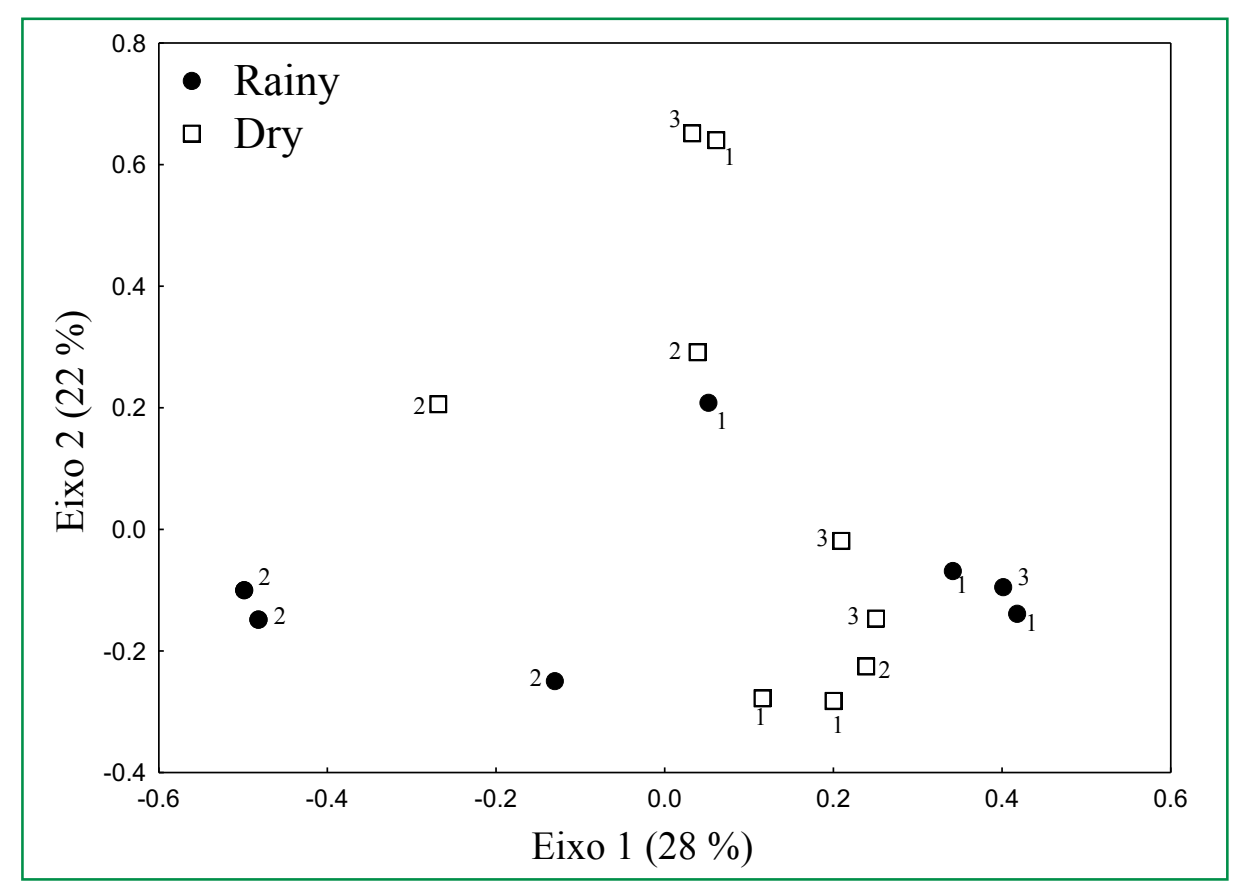




\section{Discussion}

Our results support the null hypothesis that, at the time of study, the landfill had no clear effect on aquatic insect communities. Richness of genera, abundance of individuals and composition of genera did not differ between sites with direct influence, indirect influence and without influence (upstream control) of the landfill. These results demonstrate empirically that the implementation of environmentally sound standards for solid waste management (such as PNRS) can greatly minimize the impact of landfill sites on surrounding areas, including streams, and the highly-sensitive fauna (mainly insects of Ephemeroptera orders Plecoptera and Trichoptera) that live within these fragile environments (COUCEIRO et al., 2007; 2012; LIGEIRO et al., 2013).

For the maintenance of aquatic communities in areas where there are human pressures on the landscape, it is critical to preserve riparian habitats, since these areas can act as a filter, and dampens the negative impacts of anthropogenic activities on aquatic environments (CARVALHO et al., 2013; MONTEIRO-JÚNIOR et al., 2013; VIEIRA et al., 2015; RODRIGUES et al., 2016) filtering particulates of the contaminants coming from adjacent areas and preventing them from entering the stream (ALLAN; CASTILLO, 2007). When the level of surface water contamination draining from the higher parts of the basin is low, water quality (ALLAN, 2004) and the biological communities will not be affected (COUCEIRO et al., 2007; MONTEIRO JÚNIOR et al., 2014). Thus, our study indicated that the measures deployed in PNRS are effective in mitigating the potential negative impact of landfills on streams. However, we strongly recommend that existing laws requiring the maintenance of riparian vegetation are respected in areas close to landfill sites to minimize negative effects on aquatic biodiversity in the event of an accident or failure to contain solid waste or runoff at the landfill.

The variations found between samples during dry and rainy seasons are known to Cerrado streams (BISPO; OLIVEIRA, 2007). These changes in the communities are related to seasonal variations of environmental conditions of the streams throughout the year. During the dry period, there is a decrease in width, depth and dissolved oxygen and increase in temperature of streams (GIEHL et al., 2015). This period also has the greatest diversity of aquatic insects (BISPO; OLIVEIRA, 2007), which is mainly related to the temporal variations of environmental and biotic characteristics (BRASIL et al., 2016).

There was no change in any aspect of the macroinvertebrate community as a result of the landfill. The only changes observed in macroinvertebrate communities occurred between the dry and rainy seasons, which were related to the seasonality and consequential changes in environmental conditions of water over the year. Our study, although limited, showed primary and also pioneering evidence that the PNRS can contribute positively to the conservation of the biotic quality of aquatic environments, further reinforcing the need for immediate implementation of PNRS nationwide. In addition, constant evaluation is necessary in areas subjected to high-intensity anthropogenic impacts (as in this study), including using biological communities to monitor the effects of such impacts and recovery processes of areas already affected.

\section{Acknowledgements}

We thank the Mariana Galassi Pavan for the identification of the taxons and João Alves de Lima Filho and Pericles Aquino Botelho for help in the collections. We thank the Omega Ambiental, Consutorias e Projetos and Sanorte, Saneamento Ambiental Ltda for their support during field sampling. Leandro Schlemmer Brasil thank PhD scholarship (Process 140111/2015-8).

\section{Referências}

ALLAN, J. D. Landscape and riverscapes: the influence of land use on river ecosystems. Annual Review of Ecology, Evolution, and Systematics, Palo Alto, v. 35, p. 257-284, 2004.

ALLAN, J. D.; CASTILLO, M. M. Stream ecology: structure and function of running waters. Michigan: Springer, 2007. $436 \mathrm{p}$.

ANDERSON, M. J.; WALSH, D. C. PERMANOVA, ANOSIM, and the Mantel test in the face of heterogeneous dispersions: what null hypothesis are you testing? Ecological Monographs, Ithaca, v. 83, n. 4 , p. 557-574, 2013. 
BISPO, P. C.; OLIVEIRA, L. G. Diversity and structure of Ephemeroptera, Plecoptera and Trichoptera (Insecta) assemblages from riffles in mountain streams of Central Brazil. Revista Brasileira de Zoologia, Curitiba, v. 24, p. 283-293, 2007.

BRASIL, L. S.; BATISTA, J. D.; GIEHL, N. F. S.; VALADÃO, M. B. X.; SANTOS, J. O. D.; Dias-Silva, K. Environmental integrity and damselfly species composition in Amazonian streams at the "arc of deforestation" region, Mato Grosso, Brazil. Acta Limnologica Brasiliensia, Botucatu, v. 26, n. 3, 278-287, 2014a.

BRASIL, L. S.; DIAS-SILVA, K.; JUNG, A.; OLIVEIRA, J. C. A.; SABINO, U.; VIEIRA, T. B. Ambiente, espaço ou conectividade: o que estrutura as comunidades de insetos aquáticos em riachos represados? Entomotropica, Maracay, v. 31, p. 155-166, 2016.

BRASIL, L. S.; JUEN, L.; CABETTE, H. S. The effects of environmental integrity on the diversity of mayflies, Leptophlebiidae (Ephemeroptera), in tropical streams of the Brazilian Cerrado. Annales de Limnologie - International Journal of Limnology, Santa Fé, v. 50, n. 4, 325-334, 2014b.

CABETTE, H. S. R.; GIEHL, N. F. S.; DIAS-SILVA, K.; JUEN, L.; BATISTA, J. D. Distribuição de Nepomorpha e Gerromorpha (Insecta: Heteroptera) da Bacia do Rio Suiá-Miçú, MT: riqueza relacionada à qualidade de água e de habitat. In: SANTOS, J. E.; GALBIALTI, C.; MOSCHINI, L. E. (Ed.). Gestão e educação ambiental: água, biodiversidade e cultura. São Carlos: Rima, 2010. p. 113-137.

CARVALHO, F. G.; OLIVEIRA-JUNIOR, J. M. B.; FARIA, A. P. J.; JUEN, L. Uso da curva abc como método para detectar o efeito de modificação antropogênica sobre assembleia de Odonata (insecta). Interciencia, Caracas, v. 38, n. 7, p. 516-522, 2013.

CELERE, M. S.; OLIVEIRA, A. S.; TREVILATO, T. M. B.; SEGURA-MUÑOZ, S. I. Metais presentes no chorume coletado no aterro sanitário de Ribeirão Preto, São Paulo, Brasil, e sua relevância para saúde pública. Cadernos de Saúde Pública, Rio de Janeiro, v. 23, p. 939-947, 2007.

COUCEIRO, S. R.; HAMADA, N.; LUZ, S. L.; FORSBERG, B. R.; PIMENTEL, T. P. Deforestation and sewage effects on aquatic macroinvertebrates in urban streams in Manaus, Amazonas, Brazil. Hydrobiologia, Brussels, v. 575, n. 1, p. 271-284, 2007.

COUCEIRO, S. R. M.; HAMADA, N.; FORSBERG, B. R.; PIMENTEL, T. P.; LUZ, S. L. B. A macroinvertebrate multimetric index to evaluate the biological condition of streams in the Central Amazon region of Brazil. Ecological Indicators, Amsterdam, v. 18, p. 118-125, 2012.

DE FRANCESCHI, F. R. A.; SANTIAGO, C. D.; LIMA, T. Q.; PUGLIESI, E. Panorama dos resíduos sólidos no Brasil: uma discussão sobre a evolução dos dados no período 2003-2014. DAE, São Paulo, p. 61-68, 2017. DOI: 10.4322/dae.2016.028.

DIAS-SILVA, K.; CABETTE, H. S.; JUEN, L. The influence of habitat integrity and physical-chemical water variables on the structure of aquatic and semi-aquatic Heteroptera. Zoologia, Curitiba, p. 27, n. 6, 918-930, 2010.

FARIA, A. P. J.; LIGEIRO, R.; CALLISTO, M.; JUEN, L. Response of aquatic insect assemblages to the activities of traditional populations in eastern Amazonia. Hydrobiologia, Brussels, p. 1-13, 2017. DOI 10.1007/s10750-017-3238-8.

FREITAS, E. D. S. M.; DEL GAUDIO, R. S. Ecological crisis, water shortage and ideologies: a critical analysis of the 2070 Letter.
Sociedade \& Natureza, Uberlândia, v. 27, n. 3, p. 439-451, 2015. GIEHL, N. F. S.; FONSECA, P. V. B.; DIAS-SILVA, K.; BRASIL, L. S.; CABETTE, H. S. R. Efeito de fatores abióticos sobre Brachymetra albinervis albinervis (Heteroptera: Gerridae). Iheringia. Série Zoolólica, Porto Alegre, v. 105, p. 411-415, 2015.

GOMES, E. R.; MOREIRA, F. G. S.; SOUSA, J. B.; ALCÂNTARA, P. B. Análise das concentrações de biogás em lixão desativado no município de Juazeiro do Norte-CE. In: CONGRESSO NORTE E NORDESTE DE PESQUISA E INOVAÇÃO, VII, 2012, Palmas. Palmas. Resumos... Palmas: CONNEPI, 2012. Vol. 7, p. 1-8.

IBGE - INSTITUTO BRASILEIRO DE GEOGRAFIA E ESTATÍSTICA. Cidades. 2015. Disponível em: <http://cidades. ibge.gov.br/xtras/uf.php?lang=\&coduf $=51 \&$ search $=$ mato-grosso $>$. Acesso em: 10 jan. 2015.

LEGENDRE, P.; LEGENDRE, L. Numerical Ecology. Amsterdam: Elsevier, 2012. 899 p.

LIGEIRO, R.; HUGHES, R. M.; KAUFMANNC, P. R.; MACEDO, D. R., FIRMIANO, K. R.; FERREIRA, W. R.; OLIVEIRA, D.; MELO, A. S.; CALLISTO, M. Defining quantitative stream disturbance gradients and the additive role of habitat variation to explain macroinvertebrate taxa richness. Ecological Indicators, Amsterdam, v. 25, p. 45-57, 2013.

LUIZA-ANDRADE, A.; BRASIL L. S.; BENONE, N. L.; SHIMANO, Y.; FARIA, A. P. J.; MONTAG, L. F. A.; DOLEDEC, S.; JUEN, L. Influence of oil palm monoculture on the taxonomic and functional composition of aquatic insect communities in eastern Brazilian Amazonia. Ecological Indicators, Amsterdam, v. 82, p. 478-483, 2017.

MMA - MINISTÉRIO DO MEIO AMBIENTE. Política Nacional de Resíduos Sólidos. 2014. Disponível em: < http://www.mma.gov. br/política-de-resíduos-sólidos>. Acesso em: 26 ago. 2014.

MONTEIRO JÚNIOR, C. S.; COUCEIRO, S. R. M.; HAMADA, N.; JUEN, L. Effect of vegetation removal for road building on richness and composition of Odonata communities in Amazonia, Brazil. International Journal of Odonatology, Abingdon, v. 16, n. 2, p. 135-144, 2013.

MONTEIRO-JÚNIOR, C. S.; JUEN, L.; HAMADA, N. Effects of urbanization on stream habitats and associated adult dragonfly and damselfly communities in central Brazilian Amazonia. Landscape and Urban Planning, San Diego, v. 127, p. 28-40, 2014.

OKSANEN, J.; KINDT, R.; LEGENDRE, P.; O'HARA, B.; STEVENS, M. H. H.; OKSANEN, M. J.; SUGGESTS, M. A. S. S. The vegan package. Community Ecology Package, v. 10, p. 631-637, 2007.

OLIVEIRA, S. D. E.; PASQUAL, A. Avaliação de parâmetros indicadores de poluição por efluente líquido de um aterro sanitário. Engenharia Sanitária e Ambiental, Rio de Janeiro, v. 9, n. 3, p. 240-249, 2004.

OLIVEIRA-JUNIOR, J. M. B.; SHIMANO, Y.; GARDNER, T. A.; HUGHES, R. M.; DE MARCO Jr, P.; JUEN, L. Neotropical dragonflies (Insecta: Odonata) as indicators of ecological condition of small streams in the eastern Amazon. Austral Ecology, Alice Springs, v. 40, p. 6, 733-744, 2015.

PINTO, N. S.; JUEN, L.; CABETTE, H. S.; DE MARCO, P. Fluctuating asymmetry and wing size of Argia tinctipennis Selys (Zygoptera: Coenagrionidae) in relation to riparian forest 
preservation status. Neotropical Entomology, Piracicaba, v. 41, n. 3, 178-185, 2012.

POSSAMAI, F. P.; VIANA, E.; SCHULZ, H. E.; COSTA, M. M.; CASAGRANDE, E. Lixões inativos na região carbonífera de Santa Catarina: análise dos riscos à saúde pública e ao meio ambiente. Temas Livres, Rio de Janeiro, v. 12, n. 1, p. 171-179, 2006.

PRIMACK, R. B.; RODRIGUES, E. Biologia da conservação. Lodrina: Planta, 2001. 100 p.

RODRIGUES, M. E.; ROQUE, F. O.; QUINTERO, J. M. O.; PENA, J. C.; DE SOUSA, D. C.; DE MARCO JR, P. Nonlinear responses in damselfly community along a gradient of habitat loss in a savanna landscape. Biological Conservation, Boston, v. 194, p. 113-120, 2016.

ROSENBERG, D. M.; RESH, V. H. Introduction to freshwater biomonitoring and benthic macroinvertebrates. In: ROSENBERG, D. M.; RESH, V. H. (Ed.). Freshwater biomonitoring and benthic macroinvertebrates. New York: Chapmam and Hall, 1993. p. 195233.

RUARO, R.; GUBIANI, E. A.; CUNICO, A. M.; MORETTO, Y.; PIANA, P. A. Comparison of fish and macroinvertebrates as bioindicators of Neotropical streams. Environmental Monitoring and Assessment, Dordrecht, v. 188, n. 1, p. 1-13, 2016.
SAMUEL-ROSA, A. S.; DALMOLIN, R. S. D.; COPETTI, A. C. C. A poluição causada por aterros de resíduos sólidos urbanos sobre os recursos hídricos. Ciência e Natura, Santa Maria, v. 34, n. 1, p. 107-118, 2012.

SANORTE. Sanorte Ambiente LTDA. 2014. Disponível em: $<$ http://sanorteambiental.com.br/author/sanorte/>. Acesso em: 26 ago. 2014.

SIEGLOCH, A. E.; SCHMITT, R., SPIES, M.; PETRUCIO, M.; HERNÁNDEZ, M. I. M. Effects of small changes in riparian forest complexity on aquatic insect bioindicators in Brazilian subtropical streams. Marine and Freshwater Research, Collingwood v. 68, p. 3, 519-527, 2017.

VIEIRA, T. B.; DIAS-SILVA, K.; PACÍFICO, E. S. Effects of riparian vegetation integrity on fish and Heteroptera communities. Applied Ecology and Environmental Research, Budapest, v. 13, p. 53-65, 2015.

ZAR, J. Biostatistical Analysis. Upper Saddle River: Prentice Hall, 2010. 944 p. 